\title{
'We are surviving well': Adaptive strategies applied by women in an underground South African mine
}

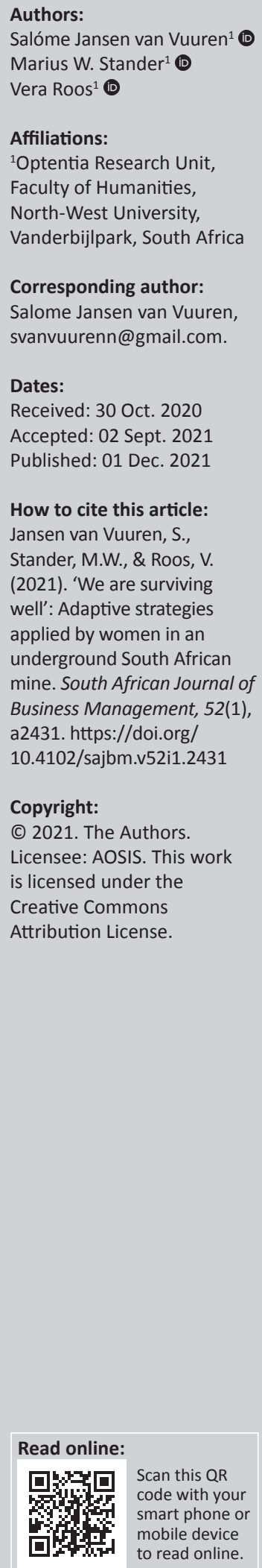

Purpose: Research into women working in mines in general is limited, and less so for their presence in underground mines. This study explores the adaptive strategies women employ to navigate harsh physical and perceived threatening interpersonal contexts in an underground mine in South Africa. A contexulalised framework and guiding heuristic contructs (structuration and agency) were adopted to identify and discuss women's adaptive strategies for navigating challenging underground mining environments and to propose interventions.

Design/methodology/approach: A contextual, qualitative descriptive design was used. Twenty-one women in an underground gold mine in the North-West Province in South Africa were purposively selected and participated in semi-structured interviews $(n=18)$ and an informal group discussion $(n=3$ ). Data was analysed thematically, using ATLAS.ti 8 (a qualitative data analysis and research software programme).

Findings/Results: The women identified challenges on three levels: intrapersonal, relational and systemic and adaptive strategies on four levels: intrapersonal (adopting a different perspective and questioning traditional beliefs), behavioural (self-defence, solution-focused actions, working hard); relational (supportive same-gendered groups, support from working teams, and safe interpersonal spaces for debriefing); and broader systemic support (approachable human resources (HR) department, supportive close relationships, and external stakeholder resourcing).

Practical implications: Interventions are proposed to support and strengthen the adaptive strategies of women working in mines.

Originality/value: Identifying and supporting adaptive strategies applied by women in the workplace can benefit women individually and their work-teams, as well as informing best mining practices and society more widely.

Keywords: gender theory; women; business research; female; entrepreneur; leadership; owner; work.

\section{Introduction}

Historically, legislation has prohibited women from being employed in mining activities in the formal mining industry (Damaske, 2011; Worldwide Recruitment Solutions, 2014). The United Kingdom (UK) promulgated legislation between 1842 and 1933 to exclude women from the workforce in mines, following the report of the Royal Commission in August 1840 on working conditions and treatment of women and children in mines (Government of the United Kingdom Parliament, 1842). Germany, North America, Sweden, Russia and Japan followed suit (Alexander, 2007; Mudimba, 2018). In 1935, the International Labour Organization (ILO) agreement stated in article 2 that 'no woman, regardless of her age, shall work underground in a mine' (Drägerwerk, n.d.). Only in 2008 did the European Court of Justice rule that this contravened the principle of equal opportunities for men and women regarding access to employment (Drägerwerk, n.d.) although women in the United States of America (US) have been employed in mining activities since the early 1970s (Cavender, 1988).

In Sub-Saharan Africa (SSA), the employment of women in the mining industry should be contextualised against its colonial history and resultant cultural marginalisation, racial and gender discrimination and lack of legal and economic rights (Arthur-Holmes \& Abrefa Busia, 2021; Musonda, 2020). Moreover, the deep infiltration of Chinese mining entrepreneurs and their reservation of job opportunities for expats led to the lesser employment of citizens, including 
women, in the countries where the mines are situated (Wegenast, Krauser, Strüver, \& Giesen, 2019). Even though several policy frameworks and commissions have emerged in the past decade to level the field for women employment, their participation remains lagging (Krauser, Wegenast, Schneider, \& Elgersma, 2019; Orleans-Boham, Sakyi-Addo, Tahiru, \& Amankwah, 2020).

Previously, South African legislation also prevented women's entry into sectors such as the mining industry. The South African Minerals Act (Act 50 of 1991) legally enforced the exclusion of women from working underground in mines (AngloGold Ashanti, 2007; Benya, 2009; De Klerk, 2012; Mokotong, 2016). Only after the adoption of the Mines Health and Safety Act of 1996 did women legally gain the right to work underground in the mining sector (Ralushai, 2003). Protection and freedom were further afforded to women with the provision of Section 6 of the Employment Equity Act of 1998; in addition to prohibiting sex/gender discrimination, it permits women to be accorded preferential treatment, but mining activities in the global mining industry were for long exclusively male dominated (Drägerwerk, n.d.; Worldwide Recruitment Solutions, 2014).

Limited research has been done on women employment in the South African mining industry. Previous studies of the industry have mainly focused on the management of men and women (Botha \& Cronje, 2015b), women's experiences concerning race and gender (Botha, 2013a; Pretorius, 2016) and on topics such as career progress, opencast mining (Moalusi \& Jones, 2019) and partly opencast mining (Botha \& Cronje, 2015b), health and safety (Botha \& Cronje, 2015a) or sexual harassment (Botha, 2016a). The literature indicates that women are particularly appreciated for their cautiousness, for example, when operating machinery, their compliance as subordinates, their low absenteeismand for their positive impact on their male counterparts (Lahiri-Dutt \& Macintyre, 2006), but there is hardly any evidence focusing primarily on women's adaptive strategies in an underground mining setting.

\section{Aim of the study}

This study is a first attempt to narrow the research gap by exploring the strategies women employ to navigate physical and social contexts in their subterranean work environment.

\section{Literature review}

Mining environments operate in different ways, hence the need to contextualise the specific work environment. Mines extract deposits of gold, diamonds, platinum, coal and other metals and minerals by surface/opencast and underground mining (Oreflow, 2019). Surface mining is practised where surface rock and soil overlay a mineral deposit. In underground mining, the ore is extracted from below the earth's surface (Oreflow, 2019) by sub-surface mining, driftmining, slope mining or shaft mining (Geology Page, 2019). Mines are categorised as high-risk work environments, and mining jobs are classified as hazardous occupations (Botha \& Cronje, 2015a). Mineworkers access underground work areas through a shaft, to a depth of up to $4 \mathrm{~km}$ (Clark, Hustrulid, \& Mero, 2017; Mining Technology, 2019). Underground central lighting is limited in these working spaces and mainly illuminates the underground railway tracks that transport the mined goods. All mineworkers are therefore issued with headlamps.

In this article, we focus specifically on women in the mining industry. In the subsequent sections, a literature overview is presented as well as the theoretical framework guiding the research.

\section{Women in the mining industry}

The international and national mining industry has seen an increase in women employed, but they remain largely underrepresented at all levels (Minerals Council South Africa, 2020: Norberg \& Fältholm, 2018). Although several policy frameworks and commissions (African Mining Vision [Africa Union, 2009]; African Women's Decade 2010 [Africa Union, 2010]; Solemn Declaration on Gender Equality and Agenda 2063 [African Union, 2015]; United Nations Economic Commission for Africa, 2011 [United Nations, 2011]) have had sought to empower and improve the fortunes of women engaged in mining in SSA in the past decade (Orleans-Boham et al., 2020), it is, however, doubtful if their contribution is enough to ensure the provision of enabling workplaces for women miners.

In SSA, the largest group of women (75\%) in the mining environments is in Guinea compared to $50 \%$ in countries such as Mali and Zimbabwe (Hilson, 2002). In Ghana, as in most sub-Saharan countries, the number of women employed in artisanal and small-scale mining is increasing (OrleansBoham et al., 2020), but they are still under-represented.

Research on the reasons for the limited employment of women in SSA is scarce and thus relies on contextual understanding. Women in SSA form an integral part of the familial-organised subsistence farming (Kotsadam \& Tolonen, 2016; Wegenast et al., 2019). In this social structure, women traditionally have adopted the role of carer to the often extended family, particularly when the men find employment elsewhere and they stay at home and tend to the homestead and livestock. This arrangement contributed to the societal perceptions and gender roles associated with women that persist today (Franks, Schurink, \& Fourie, 2006). Women who are seeking employment in mines are informed by a combination of reasons: personal aspiration, earning a meaningful (sustainable) income to support their households, supporting their children's education and enhancing their well-being (Arthur-Holmes \& Busia, 2020). However, the uptake of women in mines is often threatened by workrelated conditions. The temporality of mining extraction and mine closures militate against women, who are unable to relocate because of their family responsibilities, and in turn contribute to higher levels of job insecurity. Informal, 
unregulated mining activities carry associated safety risks for women; and difficulties with integration because of stereotypical views and antagonistic behaviour towards women miners similarly inhibit their participation in the mining industry (Kotsadam \& Tolonen, 2016; Musonda, 2020; Orleans-Boham et al., 2020).

Women's participation in South African mining activities has increased in the past 16 years, following equity legislation, education and work opportunities (Franks et al., 2006; Mostert, 2009; Van den Berg \& Van Zyl, 2008). This was mostly achieved by the Mineral and Petroleum Resources Development Act of 2002 and the broad-based Socio-Economic Charter for the South African Mining Industry of 2004. Penalties for not meeting their targets resulted in nonrenewal of mining licences. Mines had to ensure that $10 \%$ of their workforce consisted of women by 2009, compared with a meagre 2\% in 2000 (AngloGold Ashanti, 2007). In 2017, women were integral to the mines' labour force, which consists of managerial, professional and capable technical professions (Minerals Council South Africa, 2018). In 2019, 56691 women were employed in mining, representing 12\% of South Africa's total mining labour force, a marked increase from 11400 in 2002 (Minerals Council South Africa, 2020; Mining Review, 2014; Mostert, 2009; Van den Berg \& Van Zyl, 2008). Technological modernisation further stimulated female employability in the industry, particularly in jobs requiring fine motor or problem-solving skills, including operating automated machines (Buthelezi, 2013; Epiroc, 2018; Lahiri-Dutt \& Macintyre, 2006; Mine Health and Safety Council, 2015; Minerals Council South Africa, 2018; Oxford, 2015; Solomons, 2015).

Employment in mines is weighted towards male employees in a number of SSA countries (Arthur-Holmes \& Busia, 2020; Musonda, 2020; Wegenast \& Beck, 2020). This can be attributed partly to the formalisation of the mining industry, in which men performed challenging physically labour as migrant labourers. These men lived together as a homogenous male workforce in the housing provided for them. Facilities did not necessarily cater for women, which left them vulnerable and easy to dismiss.

Research on women in underground mines indicated that they are confronted with several social, physiological, structural and employment challenges (Botha, 2017). These vary from subtle coercive attempts to force the women to confirm with traditionally associated behaviour such as serving their male co-workers food and water (Botha, 2016b), to quid pro quo harassment that compels them to accede to the advances of a superior or colleagues in exchange for career advancement or to avoid dismissal (Grobler, Wärnich, Carrell, Elbert, \& Hatfield, 2011; Jansen van Vuuren, 2019; Women in Mining South Africa [WiMSA], 2015). Women in predominantly male-dominated working environments can also be exposed to boundary violating acts (see Van der Kolk, 2014), whereby they are subjected to sexual harassment, which could range from inappropriate suggestions, comments and hints with sexual overtones, joking or whistling, to unwanted physical contact: touching, forced fondling or sexual assault and rape (Botha, 2016a; Grobler et al., 2011; Women in Mining Canada, 2010). The challenges women confront in a mining context emphasise the importance of human resource (HR) practitioners in monitoring the culture and wellbeing of employees, especially women, and in putting in place administrative structures to enhance the quality of the workplace, thereby fulfilling a custodial role for employees' health and safety (Johnson \& Gueutal, 2011; Parry \& Battista, 2019).

Limited research has been conducted so far to understand the adaptive strategies women employ to navigate the oftenchallenging contexts in which they function (Botha, 2017; Jenkins, 2014).

\section{Theoretical framework}

A contextualised view of women's adaptive strategies draws on the Ecological Psychological Behavioural Settings theory of Barker (1968), and two guiding heuristic constructs, namely structuration and agency (see Kholeif \& Jack, 2019; Yuthas, Dillard, \& Rogers, 2004). The settings theory proposes that behaviour - in this instance, women's adaptive strategies - is inextricably linked to the setting (underground mining environment), following the thinking of Burke et al. (2009). From a structuration conceptual viewpoint, there is an interrelationship between structures and agency, with a structure characterised as rules (normative or interpretive), and resources distinguished as being allocative (material or economic) or authoritative (within social systems and relationships). Rules represent the expected patterns in the behavioural milieu interface, what behaviour is appropriate or acceptable or not; while resources provide the means or facilities to achieve goals (Yuthas et al., 2004). Agency in this instance refers to the women as 'active agents who constantly shape and are shaped by their environments' (Lounsbury \& Mitchell, 2009, p. 215). In the reciprocal interaction between structure and people, the women employed adaptive strategies as reflexive, knowledgeable people (active agents), who exercise their ability to act (see Filion, 2021; Yuthas et al., 2004). The adaptive strategies (agency) form as part of selfregulation processes and manifest in relation to the conditions governing the social system (structuration) (Barker, 2016). Adaptive strategies are therefore formed by dynamic, mutually influential processes between people and the micro and macro environment (interpersonal, group, organisation, broader sociocultural, political and historical) (Mazzetti \& Blenkinsopp, 2012; Neal \& Christens, 2014). The interplay between people and social structures is guided by sociocultural norms (Van der Westhuizen, 2017). Very little is known about the adaptive behaviour women have developed in underground mining environments.

In this study, adaptive strategies are regarded as those behaviours that enable women to mitigate challenges, achieve goals and 'survive well' (see Botha, 2013b; Willers et al., 2013). The term 'challenges' is preferred to 'problem' or 
'threat' because it implies an optimistic view that difficulties or challenges can be overcome (Mazzetti \& Blenkinsopp, 2012). The adaptive strategies of the women studied were explored by adopting a contextualised epistemology.

\section{Research method}

Qualitative research is an appropriate research method for understanding social complexities involving individual women in the physical and social contexts of underground mines (Braun \& Clarke, 2013). Trickett (1996, p. 216) suggested that qualitative research was appropriate to understand 'how different levels of the ecological environment impinge on the way individuals and communities develop a rhythm, order their priorities, and create resources to cope with stressful life events'. A qualitative descriptive design was used to obtain information directly from the women in their work contexts (Sandelowski, 2000, 2009).

\section{Research context and participants}

A gold mine in the North West Province of South Africa with $296^{1}$ women in 31 underground occupations was identified for the study. Temperatures in this underground mine can reach extremes of $31{ }^{\circ} \mathrm{C}$ or more. Such extreme temperatures and radiation in an underground mining environment affect women mineworkers adversely, causing irregular menstrual cycles, increased menstrual flow and other gynaecological complications (Badenhorst, 2009; Benya, 2009; Zungu, 2013). All mine workers (women included) are issued with personal protective equipment (PPE), including safety boots, overalls, gloves or, depending on the nature of the workplace, specialised gear such as earplugs to protect against noise pollution (AngloGold Ashanti, 2007; Hermanus, 2007; Minerals Council South Africa, 2019; Mining Review Africa, 2019). Women mine workers are transported with their male counterparts in a metal cage that serves as a lift to carry 250 workers to the underground workspaces, which can be as deep as $4 \mathrm{~km}$ down in this mine.

Access to the mine was negotiated with the vice-president of safety and risk, who acted as gatekeeper. A purposive sample of 21 (18 individual interviews and a group of three for a focus group) of the 296 women, who spoke multiple African languages, were recruited. Participants occupying a range of underground mining positions were included in the research. This served to produce transferable knowledge applicable to other contexts (Lincoln \& Guba, 1985). Selection criteria required that participants should be women who had been employed for at least 6 months in an underground mining environment. The women were assured that participation was voluntary and gave consent after being informed about the aim of the research and what their participation entailed. Strict compliance was followed in protecting the participants' identity and privacy.

Women selected for the study were engaged in a range of jobs, from operators and assistant miners to mining officers. Their tenure at the mine ranged from 1 to 19 years, and their

1.Because of the sensitivity concerning the numbers of women and men working underground, this information could not be obtained. ages from 26 to 44 years. The women were interviewed in the language of their choice, one of the following: Sesotho, isiXhosa, Afrikaans, isiZulu. ${ }^{2}$

\section{Data-collection methods}

An interview guide was used to gather data from 21 women who participated in semi-structured interviews $(n=18)$ and informal group discussions $(n=3)$. The aim was to collect rich, detailed and contextual information, drawing on Creswell and Creswell (2018). Research assistants who spoke and understood the participants' preferred languages acted as translators. They had been trained in interviewing skills and were informed about the aim of the study. Research assistants signed confidentiality agreements stating that they would not share any information outside the interviews or from the transcribed interviews. To ensure a rigorous process, the research assistants posed probing questions in the interviewees' preferred language and gave them time to respond. The research assistants translated their responses verbally into English for the researcher. If needed, the researcher asked clarifying questions that the assistants translated to participants and then translated their answers for the researcher. Interviews lasted between $30 \mathrm{~min}-40$ min. The participant's permission was obtained to use audio recordings of the interviews. They were assured that the information would be treated with confidentiality and shared in a way that they would not be identifiable.

\section{Data analysis and trustworthiness}

A meticulous process was followed in transcribing and translating the interviews and comprised four phases: (1) the research assistants who conducted the interviews transcribed the audio recordings in the language spoken during the interview, including any follow-up questions; (2) these transcriptions were translated into English; (3) the transcriptions were back-translated from English into the language spoken during the interview and finally (4) two independent translators, who had not been involved in the preceding phases compared the transcriptions and translations to identify inconsistencies and to ensure an accurate account of the information shared by the participants. This final transcribed and translated version was used as textual data. Transcribed data were anonymised before being uploaded into the software programme. The data coders alone had access to the data.

Data were analysed using ATLAS.ti 8. Steps in the thematic analysis included: familiarising with the data, coding, theme search, identifying reviewing themes, defining and naming themes and writing-up (Braun \& Clarke, 2013). To enhance the study's rigour, data were analysed by the first author and a co-coder, who discussed differences until consensus was reached, thereby contributing to the findings' trustworthiness (see Levitt et al., 2018). Researcher bias was limited by keeping a journal and by continuously reflecting on assumptions, following Tracy (2010). 2.These are 4 of the 11 official languages of South Africa. 
Methodological coherence was achieved by aligning the research gap with an appropriate research method and coherent presentation of findings from a contextualised view. Transparency was promoted by including verbatim quotes (Levitt et al., 2018), and participant numbering was used to report the findings.

\section{Results}

To contextualise the adaptive strategies women employed in an underground mining environment, the challenges they identified as well as the themes and sub-themes are presented in Table 1.

\section{Challenges women face in underground mining environments}

These challenges were identified on three levels and are detailed next.

\section{Intrapersonal level}

Participants expressed fear and internalised gender roles and responsibilities.

Fear: This emotion emerged in participants' perception of unsafe spaces and untrustworthy people and a sense of feeling unprotected. Unsafe spaces included bathrooms located in isolated areas: 'You must walk a long distance' (Participant 1) and 'nobody will hear you scream' (Participant 2). 'Doors could not lock securely' (Participants 18, 19 and 20). The women felt unsafe in the presence of illegal miners, called zama zamas. Participant 2 expressed concern that the

TABLE 1: Challenges and adaptive strategies of women in an underground mining environment.

\begin{tabular}{ll}
\hline Theme & Sub-theme \\
\hline Challenges women face in & Intrapersonal level \\
underground mining environments & - Fear \\
- Internalised gendered roles and & responsibilities \\
& Relational level \\
& - Undermining practices \\
& - Sexual harassment and abuse \\
Systemic level & - Ineffective organisational procedures and \\
& policies \\
- Traditional gendered stereotypes & Intrapersonal \\
- Adopting a different perspective & - Questioning traditional beliefs \\
Behavioural & - Self-defence \\
- Solution-focused actions & - Working hard \\
Relational \\
- Supportive same-gendered groups \\
- Support from working teams \\
- Safe interpersonal spaces for debriefing \\
Broader systemic support \\
- Approachable human resources department \\
- Supportive close relationships \\
- External stakeholder resourcing \\
\hline
\end{tabular}

safety measures of the mines were inadequate to protect her from potentially being raped, killed or robbed: 'It's not safe'. Fear of victimisation, according to Participant 7, prevented some women from lodging complaints: 'Most of the people are scared to speak out. I think the crisis in mining is, let's break the silence'.

Internalised gendered roles and responsibilities: Women found it challenging to reconcile their internalised gendered roles and responsibilities with complying with the demands of underground mine work. Participant 11 pointed out that, as African women, they had to create the perfect home for their families:

'So being a woman, after completing your shift, there are certain responsibilities, in our tradition ... culture, ... men come home, and the food is ready. And everything is ready, they don't need to worry about the kids and the cleaning of the house and stuff like that. As a woman you need to take care of your own household, cook some food and make everybody happy. If you've got children, that will be another additional extra on somebody's plate.' (Participant \#11; Tenure: 7 years; Language: Afrikaans)

\section{Relational level}

Challenges on an interpersonal level range from subtle, undermining practices to physical and sexual abuse.

Undermining practices: Women leaders were sometimes challenged by men, who refused to obey them. These men demonstrated escalating non-compliant attempts and manoeuvred for a one-up position in their interactions with their women supervisors. They refused to comply, expressed their distrust of women leaders' competence and in extreme cases reverted to physical abuse as a means of dominating. The following illustrates this:

'They didn't believe in me and that I know what I am doing.' (Participant \#15; Tenure: 14 years; Language: Xhosa)

'I was beaten and am scared now. They once hit me for work; they were refusing to do their work.' (Participant \#2; Tenure: 13 years; Language: isiXhosa)

Women leaders also experienced undermining behaviour by their women co-workers. This, according to Participant 7, could be an expression of jealousy:

'Because even we as women, I try by all means to pull her down, instead of asking how you made it. So that is another challenge. You know women are born with jealousy.' (Participant \#7; Tenure: 1 year 6 months; Language: Sesotho)

Participants 13 and 18 confirmed this sentiment and Participant 7 concluded that the 'element of ubuntu ${ }^{3}$ is no longer there'.

Sexual harassment and abuse: The physically challenging nature of the work contributed to the potential exploitation of

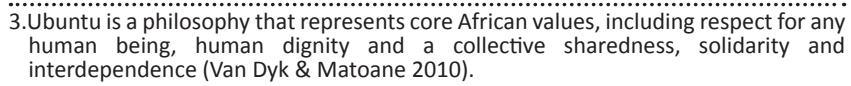
3. Ubuntu is a philosophy that represents core African values, including respect for any
human being, human dignity and a collective sharedness, solidarity and interdependence (Van Dyk \& Matoane 2010). 
the women mineworkers. For example, if they requested assistance from their male co-workers, they received it conditionally because they are expected in return to grant sexual favours. Participant 1 explained the process: 'Sometimes you are the only woman. When you are struggling somebody will say: "Okay, kiss me, for me to help you."'

Without intervention, women in this context might be exposed to ongoing sexual abuse, as mentioned by Participant 7:

'Some will rely on this man and this man will rely on their favours. So, they end up becoming sex slaves because can't manage to pick up the heavy stuff.' (Participant \#7; Tenure: 1 year 6 months; Language: Sesotho)

Underground women mineworkers were predominantly managed by men. In these situations, some women were forced to perform sexual acts for promotion. If they refused, the women faced various career-limiting consequences, such as victimisation, being sent to work in dark and isolated workstations, or even dismissal. 'He will fire you and say you don't know the work. But you know the work, [it's] just that you don't want to sleep with him' (Participant 2).

Women complained that they had been forced to perform sexual acts when working in isolation with male co-workers: 'I went to get earplugs with him. When I wanted to take them (the earplugs), he held me and kissed me' (Participant 2). Isolated workstations or enclosed workspaces provided opportunities for sexual misconduct. For example, all mineworkers were transported underground crowded together in a cage (small lift) or were standing close to one another when they were 'queuing the line to the cage (to go up)' (Participant 9). Some men used the opportunity to touch women inappropriately.

\section{Systemic level}

Challenges on organisational and broader sociocultural levels included ineffective organisational procedures and policies as well as traditional gendered stereotypes.

Ineffective organisational procedures and policies: The women stated that instances of sexual harassment or abuse went unreported or were withdrawn or pursued unsuccessfully because of a lack of evidence or witnesses. Participant 2 said: 'I laid a charge against him, but they said there was no evidence. The case was never listened to'. Male perpetrators were also seemingly protected by other men, which was observed by Participant 1: 'They like, back each other up, there won't be any witness of what you are saying', which Participant 7 confirmed: 'At some point, some (women) do lodge cases. You know, you will lodge a case and then the case is withdrawn, and you don't even know what happened'.

Traditional gendered stereotypes: In underground mining, some men expected women to fulfil a traditional, gendered role. Participant 11 recalled how a man responded to her working alongside him underground: 'What are you doing here? This is not an environment for women. I wouldn't allow my daughters to work here or my wife'. This was confirmed by Participant 14:

'[Some men] will say: "why are you here?" You said you want to work. [As a man] I can't work for a woman. A woman [her place] is at home.' (Participant \#14; Tenure: 11 years; Language: Sesotho)

\section{Adaptive strategies}

The women made use of intrapersonal, behavioural and relational strategies and wider systemic support to navigate the social and physical underground mining environment.

\section{Intrapersonal}

Two strategies emerged, namely adopting a different perspective and questioning traditional beliefs.

Adopting a different perspective: The women moved between different perspectives to confront and deal with challenges. The process started with constructive inner talk, as illustrated by Participant 2: 'I always say: tell yourself, if men can do this, you can do this'. Adopting a different perspective called for active, deliberate effort. In this regard, Participant 4 proposed:

'If you can't take a simple thing as a challenge then you will see everything as if it is there to punish you. So, once you accept your situation, you [will] enjoy your work.' (Participant \#4; Tenure: 3 years; Language: Sesotho)

Taking a different perspective meant that women were able to recognise the benefits they received when working in a challenging context, which Participant 12 confirmed:

'I think we are actually spoiled because we've got the best benefits, medical, pension. We get bonuses. So yes, we work hard and sometimes not in very nice conditions, but there are always rewards.' (Participant \#12; Tenure: 8 years; Language: Afrikaans)

A different perspective also enabled women to realise that they were in fact coping, despite challenges: 'We are surviving well' (Participant 16).

Questioning traditional beliefs: Women reminded themselves that they had the same rights as men to choose their careers, based on their interests and aptitudes. To this end, some women embarked on an internal liberation process, as Participant 11 described:

'I am also blessed with certain intellect. If I am interested in maths and science, why must I, because I am a woman, avoid those types of jobs? Why must women just be a teacher as it used to be? I got the same fitness required from me. I [being a woman] can do the job. I might be slower than you as a man, but I can still do the same job output basically.' (Participant \#11; Tenure: 8 years; Language: Afrikaans)

Women set clear employment goals and pursued them with determination and perseverance, as Participant 2 did: 
'[I] came to the mine, I wanted to work. Only men work here, there aren't women here. I wanted to work, and they said no women work here and I said I am going. I tried and got papers so that if I got hurt, I chose it.' (Participant \#2; Tenure: 13 years; Language: isiXhosa)

Participant 7 confirmed that the effort it took to find a job in an underground mining environment would not divert her focus or force her to conform to acts against her will:

'I fought my battles without allowing any men to touch me. ... I worked hard to get here, to get my qualification. So, nobody is going to bully me around. I refuse to be used as an object. I refuse to be treated as a slave or something. You are not going to make me do that.' (Participant \#7; Tenure: 1 year 6 months; Language: Sesotho)

\section{Behavioural}

The behavioural strategies the women employed included self-defence, solution-focused actions and consistent hard work.

Self-defence: Self-defence refers to the active protection of boundaries in response to perceived threatening behaviour. When the women were subjected to inappropriate sexual advances, they defended themselves physically and verbally. Participant 2 explained that she pushed her team leader away when he behaved inappropriately. Verbally, the women expressed their disapproval clearly when confronted with inappropriate sexual advances, as Participant 11 did:

'They actually really approach you and you know, there is no friendship relationship that they want, it is pure sex. My reaction is always: "no you are not allowed" or "no thank you, I am not interested."' (Participant \#11; Tenure: 7 years; Language: Afrikaans)

Solution-focused actions: The women selected appropriate strategies based on their estimation that certain actions would result in a particular outcome. In order to build her physical strength to do her job well, Participant 7 decided to train to become fitter:

'I had to go to the gym when I was a machine operator and built my body so my muscles can be fit. So, there are things that you can do to be able to cope.' (Participant \#7: Tenure: 19 years; Language: Sesotho)

Participant 1 also realised that physical strength would contribute to her independence from having to rely on men to help her with physically demanding duties:

'You must carry heavy stuff because even if you don't go to the gym you must still train. You must always carry heavy stuff. Carry a ten-kilo [bag of $]$ rice. Always be ready because here there are heavy things [to carry at work].' (Participant \#1; Tenure: 1 year; Language: Sesotho)

Working hard: Women chose to prove themselves by consistent hard work: 'From my side I just work until they [the men] are proved wrong' (Participant 9). This strategy seemed to change men's views because the same participant confirmed that the men had admitted their perceptions of her were wrong: 'Sometimes say, [they] took [me] for granted'.

\section{Relational}

Women employed relational strategies to mobilise protection as well as physical and emotional support from safe relationships with their female co-workers, in their teams and with managers and supervisors.

Supportive same gendered groups: In the everyday work environment, women relied on the protection of female co-workers (the buddy system) when they visited unsafe areas, such as washrooms: 'She will sort of announce that I am going to the toilet. Just look [out] for me' (Participant 1). Women also received confirmation of their shared situation from fellow women: 'I am lucky to have my colleagues, two ladies as well. We cry with each other, talk about it. It's actually more a friendship' (Participant 11).

Support from working teams: Men and women who worked in a supportive team had a shared goal to 'get the job done' (Participant 16). In these teams, support was effectively offered, according to Participant 4: 'If you work with the right people you get good support'. Participants identified specific relational qualities in a supportive team: friendliness, trust, perspective taking and empathy. The following responses by participants serve as an illustration:

'The people are friendly, the men are also friendly, if you have a problem, they help you quick, you see.' (Participant \#10; Tenure: 3 years; Language: Setwana)

'If you work as a team, then there's one man you can trust.' (Participant \#14; Tenure: 11 years; Language: Sesotho)

'If I work with a sympathetic person, he will tell me: "Sister don't go into the deep, I will remove the rocks for you."' (Participant \#1; Tenure: 1 year; Language: Sesotho)

Safe interpersonal spaces for debriefing: Line managers or supervisors who created a safe interpersonal space enabled women to express their frustrations and find support: 'I can share with my team leader' (Participant 13) and '... my frustrations [and] get the support from them' (Participant 11). A supervisor who was willing to support Participant 15 as an entry level employee contributed to her committing to a long-term underground career:

'He believed in me. I was so young at that time, but he saw me. He never gave up on me. Whenever I was having problems underground, people giving me a tough time, instead of going to the shift boss, I would rather go to him.' (Participant \#15; Tenure: 14 years; Language: isiXhosa)

This kind of support, according to Participant 7, enabled women to be as 'successful [in] completing their work underground as their male counterparts'. 


\section{Broader systemic support}

Women navigated challenges by drawing on external systems for support, such as the HR department, close relationships or other stakeholders in the industry.

Approachable human resources department: An organisation's HR department serves the invaluable function of advising employees, among others with health issues, dealing with difficult situations or finding information about appropriate resources, as explained by Participant 17:

'Then you will talk to her, whatever problem that you have and then she can, or he can, refer you to those resources. Like maybe someone provokes you, so you can go to HR for advice, or for laying a charge against somebody.' (Participant \#17; Tenure: 13 years; Language: English)

Supportive close relationships: Close relationships included husbands and boyfriends (Participants 9, 13) and sisters (Participant 10). Not every woman had a supportive close relationship: 'There is no one I can speak with about my issues' (Participant 8). Support in these contexts provided a space where the women could discuss their work challenges and experience emotional relief, which offer new perspectives, according to Participant 4: 'It's easier at home. If I have a bad day at work, I can relate to them (family). At least that burden I came with changed'.

External stakeholder resourcing: The women drew support from external stakeholders with a vested interest in the industry. Participant 12 stated that, due to her association with a South African mining society, she had access to a wide support network familiar with the kind of work done in an underground mine: 'Colleagues literally all over South Africa, female and male - in senior positions - that I look up to which I can contact for advice'.

\section{Discussion}

The findings of this research, conducted with participants in an underground mine, demonstrated that the women's individual agency is limited by social structure, sociohistorical-political contexts, time and place and culture. These women faced challenges on three levels, namely intrapersonal (fear and internalised gendered roles and responsibilities), relational (undermining practices, sexual harassment and abuse) and on a systemic level (ineffective organisational procedures and policies and traditional gendered stereotypes). The discussion focused on how social structure and social action (adaptive strategies) can be seen as interdependent, having at once resources and constraints, and how the participants despite the constraints, have taken up agency and engaged in adaptive strategies, which manifested on four levels of support: intrapersonal, behavioural, relational and systemic.

On an intrapersonal level, women navigated in a deprived physical and perceived hostile or potentially boundary- violating interpersonal context by a self-driven process to adopt a different perspective and question traditional beliefs. Adopting a different perspective, according to Vorster, Roos and Beukes (2013), enabled the women to consider both positive and negative elements associated with the challenges they are faced with in the particular setting. Women who employed this adaptive strategy demonstrated that they are 'self-interpretive and creative agents' following Filion (2021, p. 259). The women who are able to conduct a holistic appraisal of challenges create more possibilities for reacting to and dealing with their challenges. The second strategy women employed was to question the relevance of sociocultural norms or what Butler (in Van der Westhuizen, 2017, p. 14) referred to as 'implicit standard of normalisation' that guided the interpersonal space between them and men in the underground mining environment. Literature confirms that awareness guides self-regulation towards achieving goals more effectively (Botha, 2013b), and that social structures can at once enable and constrain actions (see Yuthas et al., 2004).

We observed the women using behavioural strategies: selfdefence, solution-focused actions, and hard work. These strategies may be described as the manifestation of 'intentional agency' (Kholeif \& Jack, 2019, p. 63) or 'intentional human activity' (Yuthas et al., 2004, p. 231). Self-defence served to protect boundaries, and this could, according to Van der Kolk (2014), support the women in preserving their physical integrity and ultimately their well-being and mental health. The solution-focused behaviour included selecting the behaviour they needed to upskill or become more informed as a means of compensating for their lack of physical strength to perform challenging tasks. The women also employed a strategy of consistently working hard in pursuit of self-interest, given that institutions are likely to reward hard work that results in goal achievement. Moreover, the women who consistently worked hard, reportedly changed the views of the men in their teams and informed the (respectful) treatment of the women. Intentional agency and intentional human activity are associated with the origins of social structural changes (Kholeif \& Jack, 2019).

The women employed three adaptive relational strategies: supportive same-gendered groups, support from working teams, and safe interpersonal spaces for debriefing. For support, women turned to a group with similar characteristics: other women who shared their fear of boundary violation or vulnerability and offered unconditional protection. The finding confirmed literature's claim that people tend to draw support from groups with similar characteristics (Bahns, Pickett, \& Crandall, 2012). The women also received support from their work teams. In the mines, they consist of men and women, and when teams collectively aim to achieve a shared goal, they are less affected by intergroup anxiety and more likely to display supportive behaviour, trust, perspective taking and social empathy. According to Harrell (2018), these are qualities known to promote social responsibility, collaboration and goal achievement. From a contextual view, Barker (2016) confirmed that settings in which a variety of 
skills, perspectives or temperaments are available contribute to more resilient settings. Finally, supervisors who facilitated a safe interpersonal context supported the women in debriefing about their frustrations and obtain much-needed support.

The women mobilised broader systemic support from the organisation, family and external stakeholders. An approachable HR department in this particular work environment as an authoritative resource provided the means and facilities for women to realise their objectives (see Yuthas et al., 2004). Literature confirms the importance of well-functioning and supportive HR management (Johnson \& Gueutal, 2011; Parry \& Battista, 2019). The women found support from close relationships (e.g. family members or partners), which provided opportunities to debrief, and if the women's distress was correctly mirrored and validated, it shifted their attention to increasing the possibilities for perspective-taking (see Hendix, Hunt, Luquet, \& Carlson, 2015). Not all women had access to such supportive relations, and this lack could potentially aggravate their emotional vulnerability and sense of isolation, thus highlighting the importance of a supportive workplace and external resources. Finally, the women used their resource-finding capacity to breach the boundaries of the mining institution to obtain external resourcing, drawing on the support from inter-institutional relations (see Filion, 2021).

\section{Managerial implications}

At the organisational level, the HRs department could play a facilitatory role to ensure that all employee relations, procedures and policies are in place and properly applied. Simultaneously, organisational structures and processes should support employee well-being, health and safety.

Creating optimal physical and psychological conditions (systemic) will be the biggest challenge for the mining industry. The nature of the business and the environment makes it a dangerous place to work in, and this could take time to improve or redesign. Women's entry in the mining industry is promoted by advancements in technology that require less physical strength, but instead fine motor and problem-solving skills to perform underground mining activities (Buthelezi, 2013; Lahiri-Dutt \& Macintyre, 2006; Mine Health and Safety Council, 2015; Minerals Council South Africa, 2018; Oxford, 2015; Solomons, 2015).

\section{Recommendations and limitations}

The equalising of conditions to promote the employment of women in mining should be a standing point on the national mining agenda of SSA countries. The findings of this study, which served to highlight women's adaptive strategies in an underground mining environment, informed the following recommendations:

1. Interventions should be developed and implemented across all levels of management. Managers should be trained in positive leadership skills to develop a climate where employee wellness and performance are a top priority. Specific attention could be paid to positions such as team leaders, who need to be trained in interpersonal skills, including creating rapport, handling emotions, situational awareness, respecting confidentiality, maintaining referral networks (internal and external resources) and enabling team peer support networks.

2. Management should set the tone and endorse the interventions through their leadership positions. This could, for example, involve identifying challenges and needs as well as women's adaptive strategies in a particular work area.

3. Specific focus should be placed on the integration and team cohesion of the group and addressing gender-based stereotypes. The creation of a psychologically safe environment facilitates self-assertive behaviour and the protection of boundaries. Interventions should be based on the premise that 'relationship initiation is a group process influenced by the broader group of social contacts in a local environment' (Bahns et al., 2012, p. 120). It is thus recommended that a concerted, facilitated effort be made to optimise group processes in different gendered working teams so that mine workers can meet on a personal level, develop shared goals and identify roles for achieving these collaboratively. This approach would be more effective than leaving individuals to organically find a way to deal with intergroup anxiety and social categorisation.

4. Develop safe interpersonal spaces to enable the women to express their needs effectively, access information about useful services and resources in the organisation and share knowledge and advice from different contexts, including external stakeholders, in safe group discussions.

5. Adopt a formal buddy system whereby women have a friend, colleague or mentor with whom they can share inappropriate behaviour and who could also support their integration and development as part of a formal induction programme or informal on-the-job debriefing sessions.

6. Develop workshops for policies and procedures to guide conduct and highlight consequences of misbehaviour. The policy for and reporting of any form of abuse should be clear and specifically the responsibility of team leaders.

This research is a first attempt to shed light on the adaptive strategies a group of women employed in an underground mine in South Africa. The inclusion of women from one mine yielded rich contextual data, but the extent to which the knowledge is transferrable to other underground mining contexts should be treated with caution. Nevertheless, the findings are a start and inform the need for further research in SSA underground mines, focusing on aspects such as identifying women's adaptive strategies in gendered teams, or investigating the procedural and behavioural strategies that HR departments might consider to inform systemic interventions beneficial to the employment of more women in favourable underground mining environments. 


\section{Conclusion}

Literature offers little on the subject of women's navigation of frequently harsh physical and perceived threatening interpersonal contexts in underground mining contexts. In a first attempt to fill this knowledge gap, we discovered that the women mine workers in the group studied resourcefully employed strategies on an intrapersonal, behavioural, relational level, as well as drawing on broader systemic support. We concluded that identifying and strengthening women's adaptive strategies could benefit women in underground mining environments and gendered teams' goal achievements, the overall performance of mines and eventually the wider African society.

\section{Acknowledgements Competing interests}

The authors declare that they have no financial or personal relationship(s) that may have inappropriately influenced them in writing this paper.

\section{Authors' contributions}

S.J.v.V. was the main researcher, whilst M.S. was the study leader, and V.R. was the co-study leader.

\section{Ethical considerations}

Ethical clearance was obtained from North-West University, Economic and Management Sciences Research Ethics Committee (EMS-REC), NWU-00085-19-A4.

\section{Funding information}

This research received no specific grant from any funding agency in the public, commercial or non-for-profit-sectors.

\section{Data availability}

The data that support the findings of this study are available on request from the corresponding author, S.J.v.V. The data are not publicly available because of restrictions, e.g. their containing information that could compromise the privacy of research participants.

\section{Disclaimer}

The views and opinions expressed in this article are those of the authors and do not necessarily reflect the official policy or position of any affiliated agency of the authors, and the Publisher/s.

\section{References}

Africa Union. (2009). Africa mining vision. Addis Ababa: African Union. Retrieved from www.africaminingvision.org

Africa Union. (2010). The African women's decade. Theme: Grassroots approach to gender equality and women's empowerment (GEWE). Addis Ababa: African Union. Retrieved from https://au.int

African Union. (2015). Agenda 2063. Addis Ababa: African Union. Retrieved from https://au.int
Alexander, P. (2007). Women and coal mining in India and South Africa. African Studies, 66(2), 201-222. https://doi.org/10.1080/00020180701482701

AngloGold Ashanti. (2007). Case study: Women in mining - On track to meet targets in South Africa. Annual Report to Society. Retrieved from http://www.anglogold ashanti.com

Arthur-Holmes, F., \& Abrefa Busia, K. (2021). Occupying the fringes: The struggles of women in Artisanal and small-scale gold mining in Rural Ghana - Evidence from the Prestea-Huni valley municipality. Gender Issues, 38, 156-179. https://doi. org/10.1007/s12147-020-09261-4

Arthur-Holmes, F., \& Busia, K.A. (2020). Household dynamics and the bargaining power of women in artisanal and small-scale mining in sub-Saharan Africa: $A$ Ghanaian case study. Resources Policy, 69, 101884. https://doi.org/10.1016/j. resourpol.2020.101884

Badenhorst, C.J. (2009). Occupational health and safety considerations for the employment of female workers in hard rock mines. Paper presented at the Southern African Institute of Mining and Metallurgy. Sun City: Hard Rock Safety conference, Sep 28-30.

Bahns, A.J., Pickett, K.M., \& Crandall, C.S. (2012). Social ecology of similarity: Big schools, small schools and social relationships. Group Processes \& Intergroup Relations, 15(1), 119-131. https://doi.org/10.1177/1368430211410751

Barker, J.S. (2016). Why 25 years? Notes on the long trajectory of Roger Barker's research in Oskaloosa. Ecological Psychology, 28(1), 39-53. https://doi.org/10.10 80/10407413.2016.1121744

Barker, R.B. (1968). Ecological psychology: Concepts and methods for studying the environment of human behavior. Stanford, CA: Stanford University Press.

Benya, A.P. (2009). Women in mining: A challenge to occupational culture in mines. Unpublished MA dissertation. Johannesburg: Industrial Sociology, University of Witwatersrand.

Botha, D. (2013a). Women in mining: A conceptual framework for gender issues in the South African mining sector. Unpublished PhD thesis, North-West University, Potchefstroom, South Africa.

Botha, D. (2016a). Women in mining still exploited and sexually harassed. SA Journa of Human Resource Management/SA, 14(1), a753. https://doi.org/10.4102/ sajhrm.v14i1.753

Botha, D. (2016b). Women in mining: Engaging men in the dialogue. Journal of Contemporary Management, 13(1), 954-976. Retrieved from https://hdl.handle. net/10520/EJC195782

Botha, D. (2017). Barriers to career advancement of women in mining: A qualitative analysis. South African Journal of Labour Relations, 41, 15-32. https://doi. org/10.25159/2520-3223-3766

Botha, D., \& Cronje, F. (2015a). Occupational health and safety considerations for women employed in core mining positions. South African Journal of Human Resource Management, 13(1), 1-12. https://doi.org/10.4102/sajhrm. v13i1.652

Botha, D., \& Cronje, F. (2015b). Women in mining: A conceptual framework for gender issues in the South African mining sector. South African Journal of Labour Relations, 39(1), 10-37. https://doi.org/10.25159/2520-3223/5880

Botha, K.F.H. (2013b). Self-regulation as psychological strength in South Africa: A review. In M.P. Wissing (Ed.), Well-being research in South Africa (pp. 501-516). Cham: Springer.

Braun, V., \& Clarke, V. (2013). Successful qualitative research: A practical guide for beginners. Thousand Oaks, CA: Sage.

Burke, N.J., Joseph, G., Pasick, R.J., \& Barker, J.C. (2009). Theorizing social context: Rethinking behavioral theory. Health Education \& Behaviour, 36(5_suppl), 55S-70S. https://doi-org.nwulib.nwu.ac.za/10.1177/1090198109335338

Buthelezi, N. (2013). Women making inroads into male-dominated mining sector despite challenges. Retrieved from https://m.miningweekly.com/article/ exploring-the-leadership-role-of-women-in-the-mining-industry-2013-08-02

Cavender, S. (1988). Women gain acceptance working in coal mines: Digging through stereotypes. Retrieved from https://www.csmonitor.com/1988/0711/acoal.html

Clark, G., Hustrulid, W., \& Mero, J. (2017). Mining. Retrieved from https://www. britannica.com/technology/mining/Underground-mining

Creswell, J., \& Creswell, J. (2018). Research design: Qualitative, quantitative \& mixed methods approaches (5th ed.). Thousand Oaks, CA: Sage.

Damaske, S. (2011). A 'major career woman?' How women develop early expectations about work. Gender and Society, 25(4), 409-430. https://doi.org/10.1177/ 0891243211412050

De Klerk, J.C. (2012) The perceptions of the work environment of women in core mining activities. Doctoral dissertation. Potchefstroom: North-West University.

Drägerwerk. (n.d.). Women below ground - The story of the Drägermen and women. Drägerwerk AG \& Co. Retrieved from https://www.draeger.com/en za/Home

Epiroc. (2018). Underground core drilling rigs - Epiroc. Retrieved from https://www. epiroc.com/en-us/products/drill-rigs/exploration-drill-rigs/underground-coredrill-rigs?index $=0$ \&unit=METRIC

Filion, P. (2021). Creative or instrumental planners? Agency and structure in their institutional and political economy context. Planning Theory, 20(3), 255-274. https://doi.org/10.1177/1473095220980499

Franks, K., Schurink, W., \& Fourie, L. (2006). Exploring the social construction of life roles of career-oriented women. South African Journal of Industrial Psychology, 32(1), 17-24. https://doi.org/10.4102/sajip.v32i1.222

Geology Page. (2019). Mining: What is mining? What are the 4 mining methods? Retrieved from https://www.geologypage.com/2019/04/mining-what-is-miningwhat-are-the-4-mining-methods.html 
Government of the United Kingdom Parliament. (1842). Employment of women and children in mines and collieries. Retrieved from https://api.parliament.uk/historichansard/commons/1842/jun/07/employment-of-women-and-children-in

Grobler, P.A., Wärnich, S., Carrell, M.R., Elbert, N.F., \& Hatfield, R.D. (2011). Human resource management in South Africa. London: Cengage Learning EMEA.

Harrell, S.P. (2018). 'Being human together': Positive relationships in the contexts of diversity, culture, and collective well-being. In M.A. Warren \& S.I. Donaldson (Eds.), Toward a positive psychology of relationships: New directions in theory and research (pp. 247-284). Santa Barbara, CA: Praeger.

Hendix, H., Hunt, L.H., Luquet, W., \& Carlson, J. (2015). Using the imago dialogue to deepen couple's therapy. The Journal of Individual Psychology, 71(3), 253-272. https://doi.org/10.1353/jip.2015.0029

Hermanus, M.A. (2007). Occupational health and safety in mining - Status, new developments and concerns. The Journal of the Southern African Institute of Mining and Metallurgy, 107, 531-538.

Hilson, G. (2002). Small-scale mining and its socio-economic impact in developing countries. Natural Resources Forum, 26, 3-13. https://doi.org/10.1111/14778947.00002

Jansen van Vuuren, S. (2019). Experiences of women working underground in a mining environment in South Africa. Unpublished Master's thesis. Potchefstroom: NorthWest University.

Jenkins, K. (2014). Women, mining and development: An emerging research agenda. The Extractive Industries and Society, 1(2), 329-339. https://doi.org/10.1016/j. exis.2014.08.004

Johnson, R.D., \& Gueutal, H.G. (2011). Transforming HR through technology: The use of E-HR and HRIS in organizations. Retrieved from https://www.shrm.org/hrtoday/trends-and-forecasting/special-reports-and-expert-views/Documents/HRTechnology.pdf

Kholeif, A.O.R., \& Jack, L. (2019). The paradox of embedded agency from a strong structuration perspective. An illustrative case study of resistance to change in budgeting processes. Qualitative Research in Accounting and Management 16(1), 60-92. https://doi.org/10.1108/QRAM-03-2016-0027

Kotsadam, A., \& Tolonen, A. (2016). African mining, gender, and local employment World Development, 83, 325-339. https://doi.org/10.1016/j.worlddev.2016.01.007

Krauser, M., Wegenast, T., Schneider, G., \& Elgersma, I.H. (2019). A gendered resource curse? Mineral ownership, female unemployment and domestic violence in SubSaharan Africa. Zeitschrift für Friedens-und Konfliktforschung, 8(2), 213-237. https://doi.org/10.1007/s42597-019-00019-8

Lahiri-Dutt, K., \& Macintyre, M. (2006). Women miners in developing countries: Pit women and others. Abingdon: Ashgate Publishing.

Levitt, H.M., Creswell, J.W., Josselson, R., Bamberg, M., Frost, D.M., \& Suárez-Orozco, C. (2018). Journal article reporting standards for qualitative primary, qualitative meta-analytic, and mixed methods research in psychology: The APA publications and communications board task force report. American Psychologist, 73(1) 26-46. https://doi.org/10.1037/amp0000151

Lincoln, Y.S., \& Guba, E.G. (1985). Naturalistic inquiry. Newbury Park, CA: Sage.

Lounsbury, D.W., \& Mitchell, S.G. (2009). Introduction to special issue on social ecological approaches to community health research and action. America Journal of Community Psychology, 44(3-4), 213-220. https://doi.org/10.1007/ s10464-009-9266-4

Mazzetti, A., \& Blenkinsopp, J. (2012). Evaluating a visual timeline methodology for appraisal and coping research. The British Psychological Society, 85(4), 649-665. https://doi.org/10.1111/j.2044-8325.2012.02060.x

Mine Health and Safety Council. (2015). Personal protective equipment for women in mining [Ebook] (1st ed., pp. 5-8). Sandton: Mine Health and Safety Council. Retrieved from https://mhsc.org.za/

Minerals Council South Africa. (2018). Women in mining in South Africa: Fact shee (pp. 1-4). Johannesburg: Minerals Council of South Africa. Retrieved from https:// mhsc.org.za/

Minerals Council South Africa. (2019). Women in mining in South Africa, Fact Sheet (1-4). Johannesburg: Minerals Council of South Africa. Retrieved from https:// mhsc.org.za/

Minerals Council South Africa. (2020). Women in mining in South Africa, Fact Sheet (p. 2) Johannesburg: Minerals Council of South Africa. Retrieved from https://mhsc.org.za/

Mining Review. (2014). Infographic: Women in the mining industry - What the stats say. Miningreview.com. Retrieved from https://www.miningreview.com/ infographic-women-in-the-mining-industry-what-the-stats-say/.

Mining Review Africa. (2019). Top honours for South African women in mining in global listing. Retrieved from https://www.miningreview.com/southern- africa/ top-honours-south-african-women-mining/.

Mining Technology. (2019). The top ten deepest mines in the world. Retrieved from https://www.mining-technology.com/features/feature-top-ten-deepest-mineshortd-south-africa/

Moalusi, K.P., \& Jones, C.M. (2019). Women's prospects for career advancement: Narratives of women in core mining positions in a South African mining organisation. SA Journal of Industrial Psychology/SA, 45(0), a1564. https://doi. org/10.4102/sajip.v45i0.1564

Mokotong, R.D. (2016). The coping mechanisms of women in the mining industry Unpublished doctoral dissertation. Pretoria: University of Pretoria.

Mostert, K. (2009). The balance between work and home: The relationship between work and home demands and ill health of employed females. SA Journal of Industrial Psychology, 35(1), a743. https://doi.org/10.4102/sajip.v35i1.743

Mudimba, P.C. (2018). Re-defining gender equality in the South African mining sector. Doctoral dissertation. Pretoria: University of Pretoria.
Musonda, J. (2020). Undermining gender: Women mineworkers at the rock face in a Zambian underground mine. Anthropology Southern Africa, 43(1), 32-42. https:// Zoi.org/10.1080/23323256.2020.1736945

Neal, J.W., \& Christens, B.D. (2014). Linking the levels: Network and relational perspectives for community psychology. American Journal of Community Psychology, 53(3-4), 314-323. https://doi.org/10.1007/s10464-014-9654-2

Norberg, C., \& Fältholm, Y. (2018). 'Learn to blend in!': A corpus-based analysis of the representation of women in mining. Equality, Diversity and Inclusion: An International Journal, 37(7), 698-712. https://doi.org/10.1108/EDI-12-2017-0270

Oreflow. (2019). The four main methods of mining. Retrieved from https://oreflow. com.au/the-four-main-methods-of-mining/

Orleans-Boham, H., Sakyi-Addo, G.B., Tahiru, A., \& Amankwah, R.K. (2020). Women in artisanal mining: Reflections on the impacts of a ban on operations in Ghana. The Extractive Industries and Society, 7(2), 583-586. https://doi.org/10.1016/j. exis.2020.03.004

Oxford, A. (2015). Tech may save the mining industry. Mail \& Guardian. p. 1. Retrieved from https://mg.co.za/article/2015-08-28-00-tech-may-save-the-mining-industry

Parry, E., \& Battista, V. (2019). The impact of emerging technologies on work: A review of the evidence and implications for the human resource function. Retrieved from https://emeraldopenresearch.com/articles/1-5/v1/pdf

Pretorius, C. (2016). The exploration of the experiences of white women workers in the coal mining industry of South Africa. Unpublished Master's thesis. Pretoria: University of Pretoria.

Ralushai, M. (2003). Experiences of women working on the mines: A case study from Rustenburg Platinum Mines. Mini-dissertation. Pretoria: University of Pretoria.

Sandelowski, M. (2000). Whatever happened to qualitative description? Research in Nursing \& Health, 23(4), 334-340. https://doi.org/10.1002/1098-
$240 \times(200008) 23: 4 \% 3 C 334:: A I D-N U R 9 \% 3 E 3.0 . C O ; 2-G$

Sandelowski, M. (2009). What's in a name? Qualitative description revisited. Research in Nursing \& Health, 33, 77-84. https://doi.org/10.1002/nur.20362

Solomons, I. (2015). $30 \%$ of SA's platinum now comes from mechanised mines, gold sector mulling or implementing high-tech initiatives. Creamer Media's Mining Weekly. Retrieved from https://m.miningweekly.com/article/30-of-sas-platinumnow-comes-from-mechanised-mines-gold-sector-mulling-or-implementing-hightech-initiatives-2015-12-04

Tracy, S.J. (2010). Qualitative quality: Eight 'big-tent' criteria for excellent qualitative research. Qualitative Inquiry, 16(10), 837-851. https://doi.org/10.1177/ 1077800410383121

Trickett, E.J. (1996). A future for community psychology: The contexts of diversity and the diversity of contexts. American Journal of Community Psychology, 24(2), 209-234. https://doi.org/10.1007/BF02510399

United Nations. (2011). Minerals and Africa's development: The International study group report on Africa's mineral regimes. Economic Commission for Africa. group report on Africa's mineral regimes. Economic Commission for Africa. https://archive.uneca.org/publications/minerals-and-africas-development

Van den Berg, H., \& Van Zyl, E. (2008). A cross-cultural comparison of the stress experienced by high-level career women. SA Journal of Industrial Psychology, 34(3), a726. https://doi.org/10.4102/sajip.v34i3.726

Van der Kolk, B. (2014). The body keeps the score: Brain, mind, and body in the healing of trauma. New York, NY: Penguin Books.

Van der Westhuizen, C. (2017). Sitting pretty: White Afrikaans women in postapartheid South Africa. Pietermartizburg: University of KwaZulu-Natal Press.

Van Dyk, G.A.J., \& Matoane, M. (2010) Ubuntu-oriented therapy: Prospects for counseling families affected with HIV/AIDS in sub-Saharan Africa. Journal of Psychology in Africa, 20(2), 327-334. https://doi.org/10.1080/14330237.2010.10820382

Vorster, C., Roos, V., \& Beukes, M. (2013). A psycho-diagnostic tool for psychotherapy: Interactional pattern analyses (IPA). Journal of Psychology in Africa, 23(3), 163-169. https://doi.org/10.1080/14330237.2013.10820663

Wegenast, T., \& Beck, J. (2020). Mining, rural livelihoods and food security: A disaggregated analysis of sub-Saharan Africa. World Development, 130, 104921. disaggregated analysis of sub-Saharan Africa. World
https://doi.org/10.1016/j.worlddev.2020.104921

Wegenast, T., Krauser, M., Strüver, G., \& Giesen, J. (2019). At Africa's expense? Disaggregating the employment effects of Chinese mining operations in subSaharan Africa. World Development, 118, 39-51. https://doi.org/10.1016/j. Saharan Africa. World

Willers, M., Potgieter, J.C., Khumalo, I., Malan, L., Mentz, P.J., \& Ellis, S. (2013). Coping and cultural context: Implications for psychological health and wellbeing. In M.P. Wissing (Ed.), Well-being research in South Africa (pp. 251-273). Cham: Springer.

Women in Mining Canada. (2010). Ramp-UP: A study on the status of women in Canada's mining and exploration sector. Retrieved from http://www.0101.nccdn. net/1_5/1f2/13b/0cb/RAMP-UP-Report.pdf

Women in Mining South Africa (WiMSA). (2015). WiMSA survey results 2015 Unpublished report.

Worldwide Recruitment Solutions. (2014). Let's talk about: Women in the mining industry. Mining.com. Retrieved from https://www.mining.com/lets-talk-aboutwomen-in-the-mining-industry-31775

Yuthas, K., Dillard, J.F., \& Rogers, R.K. (2004). Beyond agency and structure: Triple-loop learning. Journal of Business Ethics, 51, 229-243. https://doi. org/10.1023/B:BUSI.0000033616.14852.82

Zungu, L.I. (2013). South African guideline for the selection and provision of personal protective equipment for women in mining. Occupational Health Southern Africa, 19(3), 4-9. Retrieved from http://hdl.handle.net/10500/10404 